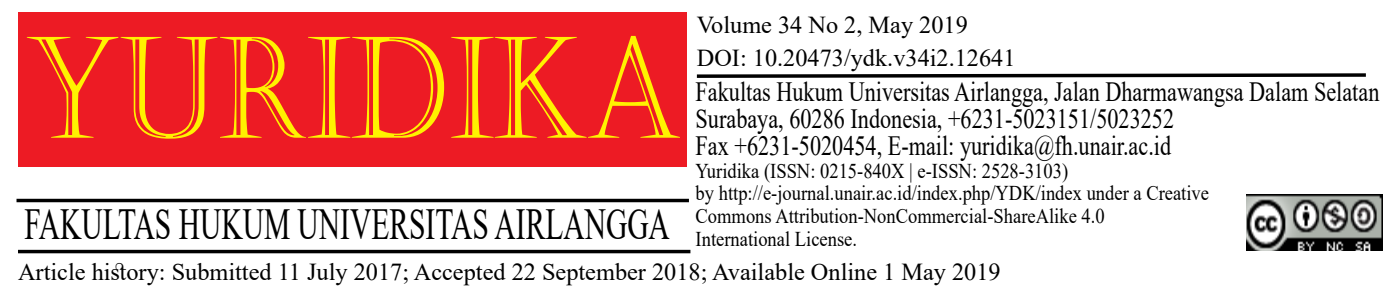

\title{
Application of Agreement Principles in Land Procurement for Development Public Interest
}

\author{
Sri Hajati \\ sri.hajati@fh.unair.ac.id \\ Universitas Airlangga
}

\begin{abstract}
The legal issues of this research consist of the application of the consensualism principle in land procurement for development for the sake of public interest. The method of this research is normative legal research by applying statute approach, conceptual approach. The results of this research: there is deviation in the enforcement of the consensualism principle in Article 66 paragraph (4) of Act Number 2 of 2012 which determines that deliberation towards consensus is not only in a form of compensation, is contrary to Article 37 paragraph (1) and (2) of Act Number 2 of 2012-which stipulates that deliberation is conducted in determining the form and/or the amount of compensation. The provision on consignment or deposit of the compensation at the court is contrary to the consensualism principle because it is conducted without the basis of mutual agreement, and it is against the essence of deliberation which requires consensus.
\end{abstract}

Keywords: Consensualism; Principle; Land Acquisition; Public Interest.

\section{Introduction}

Law Number 2 of 2012 concerning Land Procurement for Development in the Public Interest (hereinafter referred to as Law No. 2/2012) states that one of the principles underlying the procurement of land for development in the public interest is the Agreement Principle. According to the provisions of this Act what is meant by the Agreement Principle is that the process of land acquisition is carried out by deliberations of the parties without the element of coercion to obtain a collective agreement. UU No. 2/2012 this does not provide an understanding of deliberation. The definition of deliberation is contained in Presidential Regulation No. 36 of 2005 concerning Land Procurement for the Implementation of Development for Public Interest (hereinafter referred to as Perpres No. 36/2005), which was later amended by Presidential Regulation No. 65 of 2006 concerning Amendment to Presidential 
Regulation No. 36 of 2005 concerning Land Procurement for the Implementation of Development in the Public Interest (hereinafter referred to as Perpres No. 65/2006), which in Article 1 number 10 states that deliberation is an activity that contains a process of mutual listening, mutual giving, and mutual acceptance of opinions, and the desire to reach agreement on the form and amount of compensation and other problems related to land acquisition activities on the basis of voluntary and equality between parties who have land, buildings, plants, and other objects related to land, with parties who need land. and understanding of the Deliberation how it has been mentioned above, then there is an element which is the core of that understanding, namely first, that to obtain a collective agreement there must be no element of coercion, and second, on the basis of voluntary and equality between the parties.

In practice there is often disagreement regarding the amount of compensation. The following cases show this. In the case of land acquisition for East Flood Canal in Jakarta, injustice occurred in the compensation value. In this case the Land Procurement Committee denied deliberation on compensation, only by socializing land acquisition and one time compensation offer. There was no deliberation with an equal dialogue, there was also no agreement regarding the value of compensation. ${ }^{1}$ Another case that also shows the same thing is the case of land acquisition for Jombang Toll Road, East Java. In this case there is unilateral pricing and unfair enforcement, starting to force prices, breaking the concentration of landowners, pitting, intimidation and terror. There is no clarity about the details of the object of compensation, classification and price of the unit. Similarly, in the stages of land acquisition, many mechanisms were not implemented, including deliberations for pricing agreements. ${ }^{2}$ In the case of land acquisition for the expansion of Syamsudin Noor Airport in Banjarbaru, there was also no agreement on the amount of the compensation price. In the case of land acquisition for road widening on Veteran Banjarmasin road, there was also

\footnotetext{
${ }^{1}$ Bernhard Limbong, Pengadaan Tanah Untuk Pembangunan, Regulasi, Kompensasi, Penegakan Hukum (Pustaka Margaretha 2011).[210-212].

2 ibid.[222-223]
} 
disagreement about the amount of compensation. In this case the deliberation process to obtain an agreement was not carried out properly.

In addition, Law No. 2/2012 this uses a court compensation institution through the Court if an agreement through deliberation is not successful and the mechanism through the Court has been adopted. The following are some examples of cases of land acquisition which ended with the safekeeping of compensation through the Court, namely the case of the Semarang-Solo toll road project, in Semarang Regency ${ }^{3}$ consignment at the Jombang District Court in the case of land acquisition for the Jombang Toll Road 4 consignment at the Medan District Court in the case of the Surip land on Jalan Karya Jasa, Medan ${ }^{5}$ consignment in the Lubuk Pakam District Court on the Kuala Namu Airport ${ }^{6}$ project case consignment in the Tanjung Balai District Court in the case of the expansion of the mayor's office in Tanjung Balai. ${ }^{7}$ This paper focuses on the application of the principle of agreement in the procurement of land for development in the public interest through discussion of the basic criteria of agreement in each stage of land acquisition and the amount of compensation.

The Principle of Agreement as the Basis for Procurement of Land for Public Interest

InArticle 1 number 2 of Law No. 2/2012 states that land acquisition is an activity of providing land by providing proper and fair compensation to the rightful parties. According to Article 1 number 10 No. Law 2/2012, what is meant by compensation is a proper and fair replacement to the entitled parties in the land acquisition process. The basis for granting compensation is the result of an agreement in a deliberation

\footnotetext{
${ }^{3}$ Sonny Djoko Marlijanto, 'Konsinyasi Ganti Rugi Dalam Pengadaan Tanah Untuk Kepentingan Umum (StudiPengadaan Tanah Untuk Pembangunan Proyek Jalan Tol Semarang-Solo Di Kabupaten Semarang' (2014) <www.undip.ac.id> accessed 27 June 2014.

${ }^{4}$ Bernhard Limbong (n 1).Op.Cit.[224]

${ }^{5}$ Lieke Liana Tuggali, Fungsi Sosial Hak Atas Tanah Dalam Pengadaan Tanah Untuk Kepentingan Umum (Kertas putih Communication 2010).[331]

${ }^{6}$ Marni Emmy Mustafa, 'Penawaran Pembayaran Tunai Dan Konsignasi Di Pengadilan Untuk Pengadaan Tanah Bagi Pembangunan Untuk Kepentingan Umum’ (2015) <www.ptbanding. go.id $>$ accessed 25 December 2016.

${ }^{7}$ ibid.
} 
that establishes the form and/or amount of compensation, as stipulated in Article 37 of Law No. 2/2012. Article 2 of Law No. 2/2012 This stipulates that one of the principles that form the basis for the implementation of land acquisition for public interest is the principle of agreement, which is the explanation of the article confirms that what is meant by the "principle of agreement" is that the process of land acquisition is carried out by deliberation without getting a mutual agreement. The basis of the agreement of the parties is in the preparation stage and in the implementation phase of land acquisition. In the preparation stage the agreement is carried out in public consultation activities. Article 1 number 8 of Law No. 2/2012 states that what is meant by public consultation is a dialogical communication process or deliberation between interested parties to reach understanding and agreement in planning land acquisition for development in the public interest. At the stage of land acquisition implementation, the compensation determination activities are determined to determine the form and/or amount of compensation. The result of the agreement in this deliberation is the basis for giving compensation.

The principle of agreement as stated in the explanation of Article 2 of Law No. 2/2012, and the use of the term agreement followed by the term musyawarah becomes important to note, and for this reason an understanding of deliberation is needed to understand the meaning of the agreement itself. UU No. 2/2012 does not provide an understanding of agreement and also does not provide an understanding of deliberation. The definition of deliberation is contained in the Presidential Decree Number 55 of 1993 concerning Land Procurement for the Implementation of Development in the Public Interest (hereinafter referred to as Keppres No. 55/1993) and Presidential Regulation No. 36/2005 which is now no longer valid. In Article 1 number 5 Keppres No. 55/1993 states that what is meant by deliberation is a process or activity of mutual listening with mutual acceptance of opinions and desires based on voluntary relations between the holders of land rights and those who need land, to obtain agreement on the form and amount of compensation. The same definition but with a little different is contained in Article 1 number 10 of Presidential Regulation No. 36/2005 which formulates the meaning of deliberation 
is an activity that contains the process of mutual listening, mutual giving and mutual acceptance of opinions, and the desire to reach agreement on the form and size of compensation and other issues relating to land acquisition activities on the basis of voluntary and equality between parties have land, buildings, plants, and other objects related to land with those who need land.

Moving on from the notion of agreement as stated in the Explanation of Article 2 of Law No. 2/2012 and the definition of deliberation contained in Presidential Regulation No. 36/2005, basically land acquisition is carried out through a deliberation process to reach an agreement between holders of land rights with parties/agencies that need land. From the definition of deliberation, the elements can be drawn, namely: first, there is an element of equality or equivalent; second, the element of volunteerism; third, the element of attitude to hear, give, and accept opinions; fourth, the element of desire to reach agreement on the form and amount of compensation.

In order to understand the nature of deliberation to reach an agreement, it is necessary to put forward the deliberation teaching delivered by Mohammad Koesnoe. According to Mohammad Koesnoe, ${ }^{8}$ there are three principles of customary law work, namely: 1. harmonious principles; 2.asas appropriate; and 3. barrel principle. The first principle of harmony or harmony is: "the principle whose content is closely related to the views and attitudes of people in facing life together in an environment with each other to achieve an atmosphere of living together like that which is accepted as customary is a society that is safe, peaceful and prosperous". In this atmosphere of shared life, the interests of individuals cannot be separated from each other. Furthermore, Koesnoe said that in a shared life between people like that, there are many things that need to be considered and implemented, such as attitudes and steps towards mutual understanding and acceptance; forgive the mistakes and shortcomings of others; keep away from strife

\footnotetext{
${ }^{8}$ Moh Koesnoe, Tentang Tiga Asas-Asas Kerja Untuk MenghadapiPerkara-Perkara Hukum Adat Indonesia: Dalam Lima Puluh Tahun Pendidikan Hukum Di Indonesia (Fakultas Hukum Universitas Indonesia 1974).[237].
} 
and disputes by following the attitude of giving and receiving. In short, carrying out a life together here means upholding peaceful relations with each other as human beings. ${ }^{9}$ In everyday life the principle of harmony is poured into "teachings of mutual will" or "teachings composing joint decisions" and "teachings of working together" or "teachings acting in living together" In "teachings of mutual will" or "teachings form joint decisions" There are "teachings of consensus" and "consensus teachings", whereas in "the teaching of working together" or "the teachings of acting in life together" there are "teachings of mutual cooperation" and "teachings please help. "the principle of harmony leads" to also "the teaching of completion" and "the teachings of the decision". ${ }^{10}$ The second principle is the principle of right, which refers to the realm of morality and immediately to the mind which is aimed at evaluating an event, both as an actor and as a condition. Size should be sourced from morality (good-bad) and also common sense. The essence of the teachings is appropriate or propriety is to prevent people from falling into shame. Whereas the third principle, is the principle of barrel, which is mainly used in conjunction with giving answers to a concrete problem, which is done wisely so that the parties concerned and the community accept it with relief and satisfy their needs, legal feelings, and morality, so that people's lives can walk naturally again. ${ }^{11}$

Regarding the teachings of deliberation, Koesnoe explained, the term musyawarah comes from Arabic. In indigenous peoples musyawarah contains an understanding as an act of a person with other people to form a unified joint opinion on a problem faced by the entire community. ${ }^{12}$ Furthermore, Koesnoe stated that: "as a consensus teaching affirms that in living in a society, all issues concerning the necessity of life and shared prosperity must be solved jointly by the members on the basis of their collective will". ${ }^{13}$ According to Koesnoe, "in the teaching deliberation, unanimity is an important understanding, which contains a conviction

\footnotetext{
9 ibid.[238]

${ }^{10}$ ibid

11 ibid.

${ }^{12}$ ibid

${ }^{13}$ ibid.
} 
that all the wishes of the citizens have their place in it. The will of every citizen is an inseparable part of the whole because the life of the people is the emission of life from the overall will". ${ }^{14}$

\section{Stages in Procurement of Land for Public Interest}

The stages of organizing land acquisition for public interest are stipulated in Law No. 2/2012 juncto Presidential Regulation Number 71 of 2012 concerning Implementation of Land Procurement for Development for Public Interest (State Gazette of the Republic of Indonesia of 2012 Number 156) (hereinafter referred to as Presidential Regulation No. 71/2012) in conjunction with Republic of Indonesia Presidential Regulation Number 40 of 2014 concerning Amendments On Presidential Regulation 71 of 2012 concerning the Implementation of Land Procurement for Development in the Public Interest (State Gazette of the Republic of Indonesia Number 94 of 2014) (hereinafter referred to as Presidential Regulation No. 40/2014) juncto Republic of Indonesia Presidential Regulation Number 99 of 2014 concerning Second Amendment to Presidential Regulation 71 of 2012 concerning the Implementation of Land Acquisition for Development in the Public Interest (State Gazette of the Republic of Indonesia Number 223 of 2014) (hereinafter referred to as Perpres No. 99/2014) Juncto Regulation of the President of the Republic of Indonesia Number 30 of 2015 concerning Third Amendment to 71 Year Presidential Regulation 2012 concerning Peng the existence of Land for Development in the Public Interest (State Gazette of the Republic of Indonesia of 2015 Number 55) (hereinafter referred to as Presidential Regulation No. 30/2015) juncto Republic of Indonesia Presidential Regulation Number 148 of 2015 concerning the Fourth Amendment to Presidential Regulation 71 of 2012 concerning Implementation of Land Procurement for Public Interest Development (State Gazette of the Republic of Indonesia of 2015 Number 366) (hereinafter referred to as Presidential Regulation No. 148/2015), and Regulation 
of the Head of the National Land Agency of the Republic of Indonesia Number 5 of 2012 concerning Technical Guidelines for the Implementation of Land Acquisition (hereinafter referred to as Perkaban No. 5/2012).

Land acquisition for the public interest is carried out through four stages, ${ }^{15}$ namely; planning, preparation, implementation and delivery of results. In the planning stage, the land acquisition process begins with the agency's plan that requires land to make land acquisition planning based on the Regional Spatial Plan ${ }^{16}$ and Development Priorities listed in the Medium-Term Development Plan, Strategic Plan, and Work Plan of the Government Agency concerned, based on Article 14 UU No. 2/2012. Planning for land acquisition for public interest is conveyed to the provincial government in the form of a land acquisition planning document which at least contains: the purpose and objectives of the development plan; conformity with regional spatial plans and national and regional development plans; land location; land area needed; general description of land status; estimated time for land acquisition; estimated period of implementation of development; estimated land value; and budgeting plans, based on the provisions in Articles 14 and 15 of Law No. 2/2012. Stages of preparation, on the basis of the planning documents that have been made, the agencies that require the land together with the provincial government carry out activities: a. notification of development plans; b. initial data collection on the location of the development plan; and c. public consultation development plan. Notification of the development plan is conveyed to the community on the planned location of the development both directly and indirectly. Direct notification, among others, through socialization, face-to-face, or notice. Whereas indirect notifications include print media or electronic media, based on the explanation of Article 17 of Law No. 2/2012. Notification of development plans containing information about: the purpose and objectives of the development plan; location of land

\footnotetext{
${ }^{15}$ Article 13 of Law 2/2012 juncto Article 2 of Presidential Regulation 71/2012

16 The Regional Spatial Plan is based on: a. National Spatial Planning; b. Provincial Spatial Planning; and/or c. Regency/City Spatial Planning (Article 4 of Presidential Regulation 71/2012).
} 
and land area needed; the stage of the land acquisition plan; estimated period of implementation of land acquisition; estimated period of implementation of development; and other information deemed necessary, carried out no later than 3 (three) working days after the establishment of the Preparation Team, ${ }^{17}$ regulated in Articles 11 and 14 of Presidential Regulation No. 71/2012 juncto Perpres No. 148/2015.

The initial data collection on the location of the development plan includes the initial data collection activities of the party entitled and the object of land acquisition carried out by the Preparation Team within a maximum of 30 (thirty) working days from the notification of the development plan, stipulated in Article 27 of Presidential Regulation No. 71/2012. The Preparation Team can carry out the initial data collection on the location of the development plan with the officials of the kelurahan/village or other names and the results are stated in the form of a temporary list of the construction plan locations signed by the Chairperson of the Preparation Team. This temporary list is used as material for carrying out public consultation on development plans, regulated in Article 18 of Law No. 2/2012 Juncto Article 28 Perpres No. 71/2012.

Public Consultation of the development plan is carried out to get an agreement on the location of the development plan from the entitled party. According to Article 1 number 8 Law No. 8 of Presidential Regulation No. 71/2012 which means Public Consultation is a dialogical communication process or deliberation between interested parties to reach understanding and agreement in planning land acquisition for development for the public interest. The Preparation Team conducts a Public Consultation involving the rightful parties and affected communities and

17 The Preparation Team consists of regents / mayors, work units related to the province, the agencies that require land and other relevant agencies, with the tasks of: a. carry out notification of development plans; b. conduct initial data collection on the construction site; c. carry out public consultation on development plans; d. preparing the determination of the location of development; e. announce the establishment of development sites for public interest; and f. carry out other duties related to the preparation of land acquisition for development for public interest assigned by the Governor (Article 8 paragraph (2) and Article 10 of Presidential Regulation 71/2012 juncto Perpres 148/2015). 
is carried out at the kelurahan/village office or other name or sub-district office at the site of the construction site, or the place agreed by the Preparation Team with the Eligible Parties.

In the stages of the implementation of the establishment of development sites for the public interest, agencies requiring land apply for land acquisition to the Land Agency (Article 27 of Law No. 2/2012). Land acquisition is carried out by the minister ${ }^{18}$ based on Presidential Regulation No. 148/2015 and carried out by the Head of the Regional Office of $\mathrm{BPN}^{19}$ as the Chairperson of Land Procurement Executors. The implementation of land acquisition includes: ${ }^{20}$ a. inventory and identification of ownership, ownership, use and utilization of land; b. assessment of compensation; c. deliberation for determining compensation; d. award of compensation; and e. release of agency land.

Inventory and identification of ownership, ownership, use and utilization of land, including activities: a. measurement and mapping of fields per parcel; and $b$. data collection of Entitled Parties and Land Acquisition Objects. Determination of the amount of compensation is carried out by the Chairperson of Land Procurement Executives based on the results of the assessment of Public Appraisal or Appraisal services determined by the Chairperson of Land Acquisition. In working the land appraisers use the Indonesian Assessment Standard 306 (SPI 306) in 2013 as a reference. This standard is applied to activities for assessing compensation or compensation in the context of land acquisition for development in the public

${ }^{18}$ According to the provisions of Article 1 point 16 and number 17 of Presidential Regulation $148 / 2015$, what is meant by a minister is a minister who organizes government affairs in the agrarian / land sector, while the Ministry is a government institution that administers government affairs in the land sector.

${ }_{19}$ According to the provisions of Article 1 point 18 and number 19 of Presidential Regulation $148 / 2015$ which is meant by the Regional Office of the Provincial National Land Agency, hereinafter referred to as the BPN Regional Office, the vertical BPN agency in the Province is headed by the Head of Regional Office BPN under and directly responsible to the Minister. while the Land Office is a vertical BPN agency in the district / city led by the Head of the Land Office who is under and directly responsible to the Minister through the Head of the BPN Regional Office.

${ }^{20}$ Article 27 paragraph (2) Law No. 2/2012. 
interest, including direct purchases or through exchanges. ${ }^{21}$ The Indonesian Assessment Standards are compiled by the Indonesian Assessment Standards Preparation Committee (KPSPI), which is one of the components in the Indonesian Professional Appraisal Society (MAPPI) which is the only Appraisal association recognized in Indonesia. ${ }^{22}$

In deliberation on determining compensation, the land acquisition implementer conducts deliberations with the rightful party by involving agencies that require land within 30 (thirty) working days since the results of the appraisal of the Appraiser are received by the head of land acquisition and the invitation is submitted no later than 2 (two) working day before the date of the deliberation of the determination of compensation for compensation.

If there is no agreement on the form and/or amount of compensation, the rightful party can submit an objection to the local district court within a maximum of 14 (fourteen) working days after the minutes of consultation are signed, and the district court decides the form and/or amount compensation within a maximum of 30 (thirty) working days from receipt of the objection. If there are still parties who object to the verdict of the district court, then within a maximum of 14 working days can file an appeal to the Supreme Court, and the Supreme Court must provide a decision within 30 working days after the application cassation received. The decision of the District Court/Supreme Court that has obtained legal force remains the basis for payment of compensation to the party filing the objection (Article 38 of Law 2/2012 juncto Article 73 of Presidential Regulation 71/2012).

Giving compensation is given to the party entitled to it based on the results of the assessment stipulated in the deliberations and/or decisions of the district court/ Supreme Court, and in principle is handed over directly to the rightful party, in the

${ }^{21}$ Sudjarwo Marsoem, [et. al.], Pedoman Lengkap Ganti Untung Pengadaan Tanah (Rene Book 2015).[188].

${ }^{22}$ ibid. [80-81]. 
form of: ${ }^{23}$ a. money; b. replacement land; c. resettlement; d. shareholding; or e. other forms agreed by both parties. In the event that the party has the right to reject the form and/or amount of compensation based on the results of the deliberation or the decision of the District Court/Supreme Court, then compensation is deposited in the local District Court did not file an objection to the court, compensation was deposited in the local District Court. In addition, safekeeping of compensation in court is also carried out on: ${ }^{24}$ a the party entitled to receive compensation is unknown or object of land acquisition that will be given compensation: 1. the object of a case in court; 2. the ownership is still disputed; 3. placed confiscated by the authorized official or 4. Become a guarantee at the bank. Sri Hajati further emphasized that the consignment in the procurement of land should only be carried out if there had been an agreement on the form and amount of compensation. If the consignment is still carried out, the matter is qualified as one form of violating the law and does not heed respect for land rights. ${ }^{25}$

At the time of giving compensation and the release of rights has been carried out or the provision of compensation has been deposited in the district court, ownership or rights to land from the rightful party becomes erased and evidence of their rights declared invalid and the land becomes land directly controlled by the State, thus stated in Article 43 of Law No. 2/2012.

Stages of the release of land by the agency refers to the object of land acquisition for public interest owned by the government carried out in accordance with the provisions of legislation governing the management of state/regional property, while the release of objects for public interests controlled by the government or controlled

${ }^{23}$ According to Article 1 number 3 Law No. 2/2012 juncto Article 1 number 3 of Presidential Regulation No. 71/2012, what is meant by the entitled party is the party that controls or owns the object of land acquisition. Then in the Elucidation of Article 40 of Law No. 2/2012 is explained by the party entitled to, among others: a. holder of land rights; b. management rights holders; c. nadzir for waqf land; d. owner of customary land; e. customary law community; f. party that controls State land in good faith; g. holder of land tenure; and / or h. owners of buildings, plants or other objects related to land. If unable, the party has the right because the law can give power to other parties or heirs. The power recipient can only receive power from one person who is entitled to compensation.

${ }^{24}$ Article 42 of Law No. 2/2012 Juncto Article 86 Perpres No. 71/2012.

${ }^{25}$ Sri Hajati, 'Beberapa Catatan Mengenai Peraturan Presiden No. 36 Tahun 2005' (2005) 20 Yuridika.[365]. 
by the Agency State-Owned Enterprises/Regional-Owned Enterprises are carried out based on this law (Article 45 of Presidential Regulation No. 71/2012). For the last stage, namely the submission of the results of the Submission of the results of land acquisition to the agency that needs the land to be carried out after: a. granting compensation to the party who has the right and the release of rights has been carried out; and/or b. the award of compensation has been deposited in the district court.

\section{The Principle of Agreement in the Preparation and Stage of Land Procurement Phase}

From the stages of land acquisition as mentioned above, those related to the principle of the agreement are at the stage of preparation for land acquisition and at the stage of implementation of land acquisition. At the preparation stage, an agreement is required at the time of the Public Consultation. According to Article 19 of Law No. 2/2012 Public Consultation was carried out to get the agreement on the location of the development plan from the entitled parties. The agreement obtained from the Public Consultation was outlined in the form of Minutes of Agreement (Article 19 paragraph 4 of Law No. 2/2012). Required at the deliberation stage for determining compensation. The Land Agency conducts deliberations with the parties entitled to determine the form and/or amount of compensation based on the results of the assessment of compensation carried out by the Land Appraiser. The results of the agreement in the deliberation of compensation determination are contained in the Minutes of Agreement (Article 27 paragraph 2 in conjunction with Article 37 No. Law 2/2012).

Paying attention to the principle of agreement as stated in the Explanation of Law No. 2/2012, in principle land acquisition is carried out through a deliberation process to reach an agreement between holders of land rights with parties/agencies that need land. It is seen from the meaning of deliberation contained in the Presidential Regulation No. 36/2005, there are elements, first, there is an element of equality or equivalent; second, the element of volunteerism; third, the element of attitude to hear and accept opinions; fourth, the element of desire to reach agreement on the form 
and amount of compensation. In relation to deliberation to reach this agreement, Gunanegara revealed that "the normative pattern of compensation is determined based on deliberation which is the institutionalization of original institutions that grow and develop in Indonesian society". He further said that "the essence of deliberation is unanimous agreement between landowners with the state regarding the value of compensation". ${ }^{26}$ A similar opinion was expressed by Mohammad Koesnoe, which deliberation is" a personal act with other people to form a unanimous shared opinion on a problem faced by the entire community. From that deliberation always concerns the life problems of the people concerned. ${ }^{27}$ "Koentjoro Poerbropranoto argues, deliberation is" a certain system through negotiating and negotiating until an agreement is reached". ${ }^{28}$ While the Supreme Court in its Decision Number 2263.K/ PDT/1991 dated July 28, 1993 which adjudicates cases the release of the Kedung Ombo Dam land at the cassation level formulates the meaning of deliberation as a meeting of the will between the parties involved without fear, emphasis and coercion. Furthermore, the panel of judges argued that the land acquisition committee in carrying out its duties had to be based on the principle of deliberation and consensus, and did not have the power to be forced on the landowners. According to the panel of judges "agreement and deliberation" must be true and reflect justice and material truth. The author has an opinion that is in line with Eman that deliberation is a series of activities that contain a process of mutual listening, taking and giving, and mutual acceptance of opinion (amicable solution), as well as a commitment to reach agreement on the form and magnitude of compensation and problems others relating to land acquisition activities on the basis of volunteerism, equality, equality between parties, namely those who have land, buildings, plants, and other objects related to land with those who need land. ${ }^{29}$

\footnotetext{
${ }^{26}$ Gunanegara, Rakyat Dan Negara Dalam Pengadaan Tanah Untuk Pembangunan (Tatanusa 2008).[226].

${ }_{27}$ Moh Koesnoe, Catatan-Catatan Terhadap Hukum Adat Dewasa Ini (Airlangga University Press 1978).[45].

${ }^{28}$ Koentjoro Poerbopranoto, Sedikit Tentang Sistem Pemerintahan Demokrasi (Eresco 1975).[100].

${ }^{29}$ Eman, 'Pengadaan Tanah Bagi Pelaksanaan Pembangunan Untuk Kepentingan Umum' (2008) 3 Yuridika.[15].
} 
Law 2/2012 UU No. 2/2012 did not mention Law No. 20 of 1961 concerning Revocation of Land Rights and Objects Above it (State Gazette of the Republic of Indonesia of 1961 Number 288, Supplement to the State Gazette of the Republic of Indonesia Number 2324) (hereinafter referred to as Law No. 20/1961) in the consideration of remembering it, and in its articles also does not mention the revocation of rights as a method of land acquisition. Therefore according to Eman Ramelan: "Law No. 2/2012 does not determine that revocation of land rights as a way out when land acquisition cannot be carried out because of the failure to deliberate the form and amount of compensation". ${ }^{30} \mathrm{He}$ further stated that: "In other words, according to Law No. 2/2012, revocation of land rights is not a linear way of land acquisition, while according to Presidential Regulation No. 65/2006, revocation of land rights is a linear road, when land acquisition for public interests fails to be implemented". ${ }^{31}$ At the stage of implementing land acquisition, the compensation determination activities are determined by deliberation activities to determine the form and/or amount of compensation based on the results of the compensation assessment. This assessment of compensation according to the provisions of Article 37 of Law No. 2/2012 is carried out by the Land Appraiser, which according to the provisions of Article 1 number 11 of Law No. 2/2012 juncto Article 1 number 11 Perpres No. 71/2012 juncto Perpres No. 148/2015 is an individual who evaluates independently and professionally who has obtained an assessment practice permit from the Minister of Finance and has obtained a license from the Ministry ${ }^{32}$ to calculate the value/price of the object of land acquisition. UU No. 2/2012 and its implementing regulations, namely Presidential Regulation No. 71/2012 and Perkaban No. 5/2012 do not specify the assessment standards in the legal regulations used by the Land Appraiser. In Law No. 2/2012 and its implementing regulations do not explain the position of the assessment results by this Land Appraiser, whether it

\footnotetext{
${ }^{30}$ Eman Ramelan, Hukum Pengadaan Tanah Bagi Pembangunan Untuk Kepentingan Umum Di Indonesia (Airlangga University Press 2014).[124].

${ }^{31}$ ibid.

${ }^{32}$ According to Perpres No. $148 / 2015$, what is meant by the ministry is a government institution that organizes government affairs in the land sector.
} 
is a fixed result that cannot change or can still change when deliberations are held with the rightful party.

It turns out that there is a difference between Article 34 paragraph (3) of Law No. 2/2012 Juncto Article 37 with Article 66 paragraph (4) Presidential Regulation No. 71/2012. Provisions in Article 34 paragraph (3) of Law No. 2/2012 determines the value of compensation based on the results of the Appraisal's assessment as the basis for deliberation on determining compensation. But in Article 66 paragraph (4) Presidential Regulation No. 71/2012 determined that the amount of compensation as intended as a basis for deliberation to determine the form of compensation. From the provisions of Article 66 paragraph (4), deliberation is only carried out to determine the form of compensation, and not to determine the amount of compensation, even though Article 37 paragraph (1) and paragraph (2) of Law No. 2/2012 determines that deliberations are conducted to determine the form and/or amount of compensation based on the results of the compensation assessment set forth in the minutes of the agreement. Presidential Regulation No. 71/2012 is an implementation regulation of Law No. 2/2012 so that it should not conflict with Law No. 2/2012.

Indeed, in the Academic Script the Draft Law on Land Procurement made in 2010 stated that the use of deliberative institutions in determining the amount of compensation is an obstacle. Conceptually acknowledged, deliberation institutions are appropriate and good, but in practice the agreement takes a long time when using the mechanism of deliberation. ${ }^{33}$ Therefore it is recommended to eliminate deliberation in determining the form and amount of compensation because the deliberation is no longer relevant, considering the determination of the amount of compensation determined by a professional and independent appraiser. ${ }^{34}$

In the practice of land acquisition for the Palembang-Indralaya toll road, the provisions of Article 66 paragraph (4) of Presidential Regulation No. This 71/2012

\footnotetext{
${ }^{33}$ Academic Script Draft Law on Land Acquisition for Development, 2010, Chapter II: Land Procurement: Theoretical-Academic Review.[30].

${ }^{34}$ Academic Script Draft Law on Land Acquisition for Development, 2010, Chapter V: New Paradigm of Future Land Procurement.[46].
} 
is used as a basis by the land acquisition committee not to conduct deliberations with the rightful party about the amount of compensation. This was revealed in the Determination of the Kayuagung District Court Number: 84/PDT.P/2013/PN.KAG and Determination of the Kayuagung District Court Number: 3/Pdt.P/2015/ PN.KAG. Both of these cases are similar, in essence the parties that are entitled (the applicant) feel there has never been a discussion about the amount of compensation.

Regarding the need for deliberation to reach agreement on the magnitude of this compensation, the panel of judges of the Kayuagung District Court stipulates that according to the principle of the hierarchy of legislation that stipulates higher legislation overrides lower legislation, then deliberation on the determination of compensation as referred to in Article 34 paragraph (3) Law No. 2/2012 includes deliberation to reach an agreement on the form of compensation and deliberation to reach an agreement on the amount of compensation as stipulated in Article 37 paragraph (1) and paragraph (2) of Law No. 2/2012 which stipulates that deliberations are conducted to determine the form and/or amount of compensation based on the results of the compensation assessment as outlined in the minutes of agreement, and also the provisions in Article 38 paragraph (1) of Law No. 2/2012 which is the basis of the authority of the court to decide cases of objection to the agreement regarding the form and/or amount of compensation.

Regarding whether deliberations have been held or not, the panel of judges argues that deliberation to reach an agreement on the amount of compensation in land acquisition is not interpreted as a bargaining process between Land Procurement Officers facing each other with rights holders but must be interpreted as reaching an agreement if the majority of rights holders agree and the giving of closed envelopes received by right-holders is one form of deliberation to reach an agreement, most importantly whether the majority of rights holders can approve and accept the offer so that an agreement is reached on the amount of compensation they will receive respectively.

If you pay attention to the opinion of the panel of judges in the Kayuagung District Court, this is related to the meaning of deliberation contained in the 
Presidential Regulation No. 36/2005, namely: "activities that contain the process of mutual listening, mutual giving and mutual acceptance of opinions, and the desire to reach agreement on the form and size of compensation and other issues relating to land acquisition activities on the basis of voluntary and equality between parties who own land, buildings, plants, and other objects related to the land with those who need land, "then it turns out the results of the Appraiser's assessment regarding the amount of compensation are final, there are only options to agree or disagree, so there is no mutual listening process giving and accepting opinions on the basis of volunteerism and equality. Even the deliberation process is reduced to a process of agreeing or disagreeing and the outcome of the agreement is determined by calculating the highest number (majority). Though deliberation for consensus is the basic principle that distinguishes Pancasila democracy from liberal democracy which adheres to the principle of voting and people's democracy which adheres to the principle of concentration of power (authority). ${ }^{35}$ Thus in the implementation of Law No. 2/2012 has violated the principle of "deliberation of consensus" in reaching an agreement.

Even though Law No. 2/2012 adheres to the principle of agreement and deliberation, but according to Eman Ramelan, the consignment institution is still included in Article 42 of Law No. 2/2012 which determines the reason for consignment or safekeeping of compensation if the person who has the right to reject the form and/or the amount of compensation or the decision of the District Court or the Supreme Court indicates that the consignment arrangement is contrary to the principles used in Law No. 2/2012 in particular, the principles of humanity, justice, agreement, participation and welfare. ${ }^{36}$ The use of a consignment institution known in Article 1404 Indonesia civil code is also deemed inaccurate because the consignment known in this article must begin with an agreement between the parties which underlies civil relations between the parties. If one party is unwilling to accept payment or agreed obligations, then consignment is carried out. Thus

\footnotetext{
${ }^{35}$ M Taopan, DemokrasiPancasilaAnalisisKonsepsionalAplikatif, (Sinar Grafika 1987).[51].

${ }^{36}$ Eman Ramelan (n 30).Loc.Cit.
} 
consignment can only be carried out if previously between the parties there is a legal relationship that is civil in nature and without the legal relationship, the consignment cannot be carried out. The Supreme Court has issued a decision in its decision No.2263.K/Pdt/1991 dated July 28, 1993 regarding the case of the land acquisition of the Kedung Ombo Dam which states that the legal process of consignment legal institutions is not a unilateral process, but rather answers to both parties dispute. Judges' decisions about consignment are subject to appeal and cassation legal efforts. According to Maria Sumardjono, land acquisition is an act of the government to obtain land and not civil relations between the parties. Therefore, according to him, it is wrong to apply the concept of indemnification in court to land acquisition, which is analogous to the concept of safekeeping associated with debt accounts in Article $1404 \mathrm{BW} \cdot{ }^{37}$ Forcing to use consignment as regulated in BW, besides contradicting the principle of consignment itself, it is also an arbitrary act and is a repressive and coercive action to holders of land rights. ${ }^{38} \mathrm{~A}$ similar opinion was expressed by Gunanegara that the safekeeping of unilateral compensation in court was a denial of the essence of deliberation which required a unanimous agreement. ${ }^{39}$ Thus the provisions of Article 42 of Law No. 2/2012 which determines the reason for consignment in a district court if the person has the right to reject the form and/or amount of compensation, contrary to the principle of agreement

\section{Conclusion}

Even though Law No. 2/2012 adheres to the principle of agreement and deliberation, but in its application there is a deviation from the principle of the agreement itself. Provisions of Article 66 paragraph (4) of Presidential Regulation No. 71/2012 which determines deliberations to reach agreement only for forms of compensation, contrary to the provisions of Article 37 paragraph (1) and (2) Law

${ }^{37}$ Maria Sumardjono, Tanah Dalam Persfektif Hak Ekonomi Sosial Dan Budaya (Buku Kompas 2008).[275].

${ }^{38}$ Eman Ramelan (n 30).Loc.Cit.

${ }^{39}$ Gunanegara (n 26).Loc.Cit. 
No. 2/2012 which determines deliberations to determine the form and/or amount of compensation. Provisions of Article 42 of Law No. 2/2012 which determines the reason for consignment or safekeeping of compensation in a district court if the person has the right to reject the form and/or the amount of compensation, contrary to the principle of agreement because it is done without basing an agreement from the parties, and contrary to the essence of deliberation that requires an agreement.

Therefore in determining the form and/or amount of compensation for Law No. 2/2012 adheres to the principle of agreement, so that land acquisition should be carried out through the release of rights or the surrender of land rights with the principle of deliberation to reach an agreement. If there is no agreement, then no consignment or deposit of compensation can be made to the court. If the deliberation does not produce an agreement, then it is not consignment or safekeeping that is done but should use the revocation of rights as stipulated in Law No. 20/1961, which does not require consultation to reach an agreement.

\section{Bibliography}

Bernhard Limbong, Pengadaan Tanah Untuk Pembangunan, Regulasi, Kompensasi, Penegakan Hukum (Pustaka Margaretha 2011).

Eman Ramelan, Hukum Pengadaan Tanah Bagi Pembangunan Untuk Kepentingan Umum Di Indonesia (Airlangga University Press 2014).

- ' 'Pengadaan Tanah Bagi Pelaksanaan Pembangunan Untuk Kepentingan Umum' (2008) 3 Yuridika.

Gunanegara, Rakyat Dan Negara Dalam Pengadaan Tanah Untuk Pembangunan (Tatanusa 2008).

Koentjoro Poerbopranoto, Sedikit Tentang Sistem Pemerintahan Demokrasi (Eresco 1975).

Lieke Liana Tuggali, Fungsi Sosial Hak Atas Tanah Dalam Pengadaan Tanah Untuk Kepentingan Umum (Kertas putih Communication 2010).

M Taopan, Demokrasi Pancasila Analisis Konsepsional Aplikatif (Sinar Grafika 1987). 
Marni Emmy Mustafa, 'Penawaran Pembayaran Tunai Dan Konsignasi Di Pengadilan Untuk Pengadaan Tanah Bagi Pembangunan Untuk Kepentingan Umum' (2015) <www.ptbanding.go.id> accessed 25 December 2016.

Maria Sumardjono, Tanah Dalam Persfektif Hak Ekonomi Sosial Dan Budaya (Buku Kompas 2008).

Moh Koesnoe, Tentang Tiga Asas-Asas Kerja Untuk MenghadapiPerkara-Perkara Hukum Adat Indonesia : Dalam Lima Puluh Tahun Pendidikan Hukum Di Indonesia (Fakultas Hukum Universitas Indonesia 1974).

— Catatan-Catatan Terhadap Hukum Adat Dewasa Ini (Airlangga University Press 1978).

Sri Hajati, 'Beberapa Catatan Mengenai Peraturan Presiden No. 36 Tahun 2005' (2005) 20 Yuridika

Sonny Djoko Marlijanto, 'Konsinyasi Ganti Rugi Dalam Pengadaan Tanah Untuk Kepentingan Umum (Studi Pengadaan Tanah Untuk Pembangunan Proyek Jalan Tol Semarang-Solo Di Kabupaten Semarang' (2014) <www.undip. ac.id $>$ accessed 27 June 2014.

Sudjarwo Marsoem, [et.,al.], Pedoman Lengkap Ganti Untung Pengadaan Tanah (Rene Book 2015).

HOW TO CITE: Sri Hajati, 'Application of Agreement Principles in Land Procurement For Development Public Interest' (2019) 34 Yuridika. 
--This page is intentionally left blank-- 